\title{
Review
}

\section{Politics with Beauvoir: Freedom in the encounter}

\author{
Lori Jo Marso \\ Duke University Press, 2017, xii+253 pp., \\ ISBN: 978-0-8223-6970-7
}

Contemporary Political Theory (2018) 17, S189-S192. https://doi.org/10.1057/s41296017-0160-9; published online 3 October 2017

In Lori Jo Marso's compelling re-examination of Beauvoir's political thinking, our responsibility to political thinkers of the past translates into a commitment to the present. Teasing out the implications of Beauvoir's attentiveness to the fundamental ambiguity of human existence, the book interprets this foremost 20th-century existential thinker as a theorist of encounter. It takes up Beauvoir's crucial insight that it is in affective relationships with plural others that we may discover a privileged site of politics. While acknowledging the situated character of political action, this perspective brings into view 'struggle and plurality' as constituting the space 'wherein a chance to expand or diminish freedom occurs' (pp. 4, 9). What emerges is a conversational, literary account of political thinking that is always already in dialogue with others. It suggests a form of political engagement oriented towards 'confrontation and conversion', a constant nurturing of possibilities for solidarity and collective political action (p. 10). The book not only resuscitates Beauvoir's unique political vision against attempts to domesticate it - either through rejection or veneration - under established strands of feminist thought. It also foregrounds its prescient relevance by undertaking a similar dialogical exercise in political thinking with new interlocutors and towards new concerns.

The first chapter unsettles the received philosophical and political significance of Beauvoir's The Second Sex, reading it as a series of affective encounters that are both conditioned by and able to displace the symbolic and material hierarchies of inequality. Based on this reconstruction, the book is divided into three parts, staging Beauvoir's encounters with 'enemies', 'allies' and 'friends' (p. 10). The first part inquires into the transformative potentials of Beauvoir's confrontation with enemies, Robert Brasillach and the Marquis de Sade, while also entertaining the challenging perspective of Lars von Trier. The second part evokes the company of allies, Frantz Fanon and Richard Wright, focusing on the possibilities for collective action against entrenched structures of political violence. In the third part, finally, the book builds on Beauvoir's calls to nurture connections between

(C) 2017 Macmillan Publishers Ltd. 1470-8914 Contemporary Political Theory Vol. 17, S4, S189-S192 
isolated individuals, and examines 'the freedom-enhancing potential of feminist friendship' (p. 150).

Beauvoir's critical openness to enemies comes forth in her desire to understand the unprecedented atrocities of the twentieth century, an urge most evident in her report on the trial of a fascist journalist, Robert Brasillach. Similarly to Hannah Arendt's engagement with the evil of Adolf Eichmann, Marso outlines how Beauvoir resisted the tendency to subsume the particular nature of Brasillach's crime under prefabricated rules. On the contrary, she was critical of the French court's decision to execute him for acts of treason against the French state, whereby the issue of French collaboration was explained away as an offense against the nation. Resorting to reflective judgement, Beauvoir held Brasillach responsible for the refusal to recognise the victims in the ambiguity of their embodied existence, which in effect denied their capacity to affirm freedom in the world. From this encounter stem important insights on how to nourish conditions for a properly human existence. In contrast to Arendt, Marso argues, Beauvoir draws attention to relationships of power and inequality, which place certain individuals or groups in positions of heightened vulnerability to oppression. Marso further explores the destructive effects of political violence by engaging Lars von Trier's Antichrist, often considered the misogynist film par excellence. Akin to Beauvoir's unprejudiced reading of the Marquis de Sade, Marso shows how von Trier's corporeal images of aberrant femininity expose the systematic, often hidden violence of liberal humanism and its patriarchal structures of representation and knowledge. In the strange realities conjured by the film, we are invited to see an opening towards a different way of communication that may allow us to 'feel our way beyond patriarchy' (p. 90).

Beauvoir's awareness of the pervasiveness of violence led to a heightened attentiveness to the antinomies of resistant action. Her encounter with Fanon reveals how we might think of pathologies engendered by oppression not as individual afflictions but as poignant sites of dissent and collective resistance. Here Beauvoir both echoes and moves beyond the recent scholarship that emphasises the political significance of embodiment and affect, never losing sight of the human potentials for freedom (pp. 100-101). This section also discusses Beauvoir's concern with the spectre of risk and failure haunting political action, including the troubling fact that the fight for freedom for all might itself require the use of violence. Nevertheless, the centre of attention lies on examining how the wounded psyches of the oppressed might move beyond reinstating patterns of systemic violence and enact alternative forms of communion. As is evident from Beauvoir's encounter with Wright, the proposed type of solidarity is not grounded in a given oppressed identity, but must be brought into being through conversation between a plurality of lived experiences, across class, race, nation and gender boundaries.

Lastly, the book addresses the false promise of sovereign agency and group identity by turning to Beauvoir's commitment to friendship. Developing the 
political relevance of Beauvoir's dialogical thinking, Marso considers several literary and cinematic conversations between women, exploring how they foreground the intimate as a politically powerful source of critique. Marso first investigates Chantal Akerman's Jeanne Dielman, David Fincher's Gone Girl and Lars von Trier's Nymphomaniac, all depicting women in situations of oppression, alone and shorn of 'sororal' bonds (p. 173). She reads the heroines' seemingly pathological behaviour as attempts at resistance, which, however, also demonstrate the urgent need for companionship. On this basis, the book ponders the political import of Beauvoir's friendship with Violette Leduc as depicted in Martin Provost's film Violette, Arendt's conversation with Rahel Varnhagen in her biography Rahel Varnhagen: The Life of a Jewess and Margarethe von Trotta's dialogue with Arendt in her film Hannah Arendt. The political significance of feminist friendship, on this account, cannot lie merely in a demand for equal or more progressive representation, such as increasing the number of women on the screen (or in public life). Marso's search is for a horizontal thinking with others, where the rules and relationships can be redrawn only if we embrace the joy of encounter - along with all the risks and unpredictability it entails.

It is the utmost value of the book to displace the focus on individual agency on the one hand, and the constraints of structure, on the other. Marso's creative appropriation of Beauvoir's literary approach, instead, lingers in that place where agency and structure interlace, revealing the possibilities and limits of political action as they are negotiated in and through concrete interrelationships between a plurality of subjects. The book's focus on the political significance of literary sensibility importantly speaks to the field of narrative ethics. If recent writings on narrative go as far as to question its meaning-creating potentials, Marso's conversational thinking delves into the aesthetic features of literature and film to unearth the specific relationships and dynamics of power they embody. Thus it also invites an exploration of what aesthetic choices might be most conducive to fashioning, amidst the entrenched structures of violence, the (however limited) space for the movement of human freedom. The book also is to be praised for opening a fruitful dialogue between Beauvoir and Arendt, two thinkers that, despite many common concerns, have not been put in a sustained dialogue. Yet, the relationship between Beauvoir's encounter and Arendt's notion of the in-between of the world would merit more nuanced elaboration. While Beauvoir points to the ways the private facts of our existence are shaped by oppressive configurations of meaning, Arendt asks how these meanings could be confronted politically, rather than evaded in affirmations of inner states or social attitudes. Together, the two thinkers offer resources for extending intimate encounters between (two) friends to the political realm of the many, and disclosing spaces of shared responsibility for worldly structures of oppression that lie beyond any individual's control. Such a politics of the in-between, further, draws attention to the need to examine the ambivalent role of violence in resistant politics - a concern that is implied at

(C) 2017 Macmillan Publishers Ltd. 1470-8914 Contemporary Political Theory Vol. 17, S4, S189-S192 S191 
various points in the discussion. A closer examination of the ambiguous relationship between violence and politics in the two thinkers' work, in particular, might move the debate beyond Beauvoir's recognition of failure, and towards a careful scrutiny of the possibilities for transforming the relations of enmity into those of civic friendship.

To conclude, replacing the logic of sovereignty with the promise of mutuality, the book pushes Beauvoir's thought into the future. It foregrounds its significance not only to questions of how to reconstitute a meaningful human existence after egregious human rights violations that elude established categories, but also to exposing the invisible complicities in everyday systemic violence. Making Beauvoir speak in new contexts, it appeals to us to constantly probe the political meanings of interpersonal relationships, and reconsider the scope of individual responsibility. The book's 'happy ending' (p. 203) - as Marso refers to the 'joys of encounter' - can best be interpreted as Arendt's miracle of beginning that in itself has no end (Arendt, 1994, p. 320).

\section{Reference}

Arendt, H. (1994). Essays in Understanding, 1930-1954. Ed. J. Kohn. New York: Schocken.

Maša Mrovlje
University of Edinburgh, Edinburgh EH8 9YL, Scotland, UK
masa.mrovlje@ed.ac.uk

